Modern Asian Studies 44, 2 (2010) pp. 401-440. (C) Cambridge University Press 2008 doi:10.1017/S0026749X08003508 First published online 29 October 2008

\title{
Modern Burma Studies: A Survey of the Field
}

\author{
ANDREW SELTH
}

\author{
Research Fellow, Griffith Asia Institute, Griffith University, Nathan Campus, \\ I 70 Kessells Road, Brisbane, Queensland 4 I I I, Australia \\ E-mail: a.selth@griffth.edu.au
}

\begin{abstract}
Burma has never been a popular subject for academic research but, since a massive pro-democracy uprising drew worldwide attention to the country in 1988, the number of scholars and students engaged in the field has grown considerably. However, they still face a number of major challenges. Along with other kinds of area studies, Burma studies have been accused by academics from the more 'scientific' disciplines of being too narrowly focused and lacking theoretical rigour. Also, it has been difficult to conduct research in Burma's closed society. While the latest military government has relaxed some controls, field work is still constrained and reliable sources are hard to find. Often, the knowledge gap has been filled by myths and misconceptions. Adding to these problems, since 1988 the Burma studies community has become highly polarised, with political and moral factors often featuring more prominently in the public debate than considered arguments based on objective analysis. All these factors have adversely affected modern Burma studies and restricted understanding of this deeply troubled country by both scholars and the wider community.
\end{abstract}

All that is said here is only an introduction to a subject so vast that, if you became re-incarnate in Burma for twenty lives, you would still be only upon the threshold of greater discoveries. The increasing interest would still lure you irresistably forward to further research.

$$
\begin{array}{r}
\text { C. M. Enriquez } \\
\text { A Burmese Enchantment }(1916)^{1}
\end{array}
$$

${ }^{1}$ C. M. Enriquez, A Burmese Enchantment (Thacker, Spink and Co., Calcutta, 1916), p. vi.

CAMBRIDGE JOURNALS 4 O 1 


\section{Introduction}

Burma has never been a popular subject for research and analysis among scholars outside the country. Compared to the collections found on many other places, the literature on Burma is relatively small. Nor has Burma enjoyed a high profile in broader works devoted to the major academic disciplines, like economics or political science. Yet, over the past century, Burma studies has slowly but firmly established itself as a discreet field of enquiry, mainly in the United States (US), Europe, Russia and Japan. Since the political turmoil of 1988, it has attracted a new generation of scholars, not only from these countries but also from Australia and Southeast Asia, including from Burma itself. The tragic events of September 2007 seem likely to encourage this trend.

'Burma studies' is a portmanteau term commonly used in universities and institutes around the world to describe the work of specialists from a wide range of different academic disciplines, such as history, political science, economics, anthropology, archaeology, religious studies and art history, who are conducting research focused on the geographical area or political entity currently recognised as the state of Burma (or Myanmar). ${ }^{2}$ This work is often based on knowledge of the Burmese language, or a language of one of Burma's main ethnic groups, such as Mon, Karen or Shan. In this sense, Burma studies can be viewed as a sub-division of 'Asian studies', itself a subset of the much broader category of academic activity that, since the 1940s, has come to be known as 'area studies'. ${ }^{3}$

Over the past $5^{0}$ years, area studies have suffered from a bad press in academic circles. Some commentators-particularly from the more structured and theoretical disciplines-have tended to view area studies as outdated, and even discredited. While it is usually acknowledged that they are deeply textured and highly nuanced, area

${ }^{2}$ In 1989, Burma's new military government changed the country's name to Myanmar. At the same time, a number of other place names were changed to conform more closely to their original Burmese pronunciation. For example, Rangoon became Yangon. In this article the older forms are used, for ease of recognition. Citations, however, are given as they were originally published.

${ }^{3}$ Area studies are sometimes described as a form of cultural studies, and in some catalogues of academic disciplines are listed under the humanities and the arts, rather than the social sciences. While such divisions are essentially arbitrary, modern Asian (and other area) studies invariably encompass much more than 'the meaning and practices of everday life among Asian peoples', by 'combining aspects of sociology and cultural anthropology'. See <http://www.answers.com/topic/asian-studies $>$ 
studies have been criticised for lacking 'generalisability' or theoretical rigour within a specific field or discipline. Yet, despite these concerns, in recent years Burma studies have attracted a higher level of academic interest. The term remains a useful way to describe a wide variety of important research programs, by scholars from many different academic backgrounds, who have in common a professional interest in Burma. That said, the origins and development of Burma studies are still poorly understood, even by some practitioners in the field.

This paper aims to provide a brief survey of modern Burma studies, by describing their evolution, their relationship with other academic disciplines, and their current status. It also canvasses the various problems Burma scholars have encountered, and still face, both within and outside Burma.

While it necessarily touches on academic work being conducted inside Burma, this paper is concerned mainly with the interest shown in Burma by foreign scholars writing in English. Also, it focuses on works that belong to the modern international tradition of academic enquiry and only mentions briefly serious reportage of, and comment on, the contemporary Burma scene. While it refers to a wide range of publications, mainly as illustrative examples, this paper makes no claim to be a comprehensive literature review. Nor does it seek to provide an authoritative account of the development of a broad and multi-faceted field of academic activity that invites many different perspectives. Even if such an undertaking were possible, it would require far more space than is available here. To borrow the words of a pioneer in the field of Southeast Asian studies, this survey is necessarily 'a bare outline, perilously compressed and oversimplified in many parts'. 4

Most scholars studying Burma have adopted the convention of dividing it into historical periods. The three-stage British conquest of the country in the nineteenth century, for example, has usually been accepted as marking a 'fundamental break in the pattern of Burma's development'. ${ }^{5}$ Major political events after that, such as the Second World War, Burma's Independence in 1948, General Ne Win's coup

${ }^{4}$ D. G. E. Hall, 'Preface to the First [1955] Edition', A History of South-East Asia (Macmillan, London, 1970), p. xx.

${ }^{5}$ V. B. Lieberman, 'Reinterpreting Burmese History', Comparative Studies in Society and History, Vol. 29, No. 1 (January 1987), pp. 162-94. The UK annexed the coastal areas of Arakan and Tenasserim in the First Anglo-Burmese War of 1824-26, took Lower Burma by force of arms in $185^{2}$ and overthrew the Burmese king in Mandalay after a third military campaign in 1885 . 
d'etat in 1962 and the advent of a new military regime in 1988, have all been seen as critical turning points in the country's history. A few scholars have challenged such a linear approach, and emphasised the social, economic and political continuities between various Burmese dynasties, between 'classical' Burma and the colonial period, and even between Burma prior to the British conquest and modern times. ${ }^{6}$ The essentially arbitrary nature of the standard periodisation model and its limitations are recognised, but this structure still has a certain heuristic value and thus has been adopted in the discussion that follows.

\section{Burma Studies Before 1948}

Arguably, there is a long tradition of indigenous Burmese scholarship, dating back to the eleventh century. Inscriptions found in the ancient capital of Pagan, for example, 'contain the traces of historical writing', although the chronicles of the fifteenth century are more commonly seen as marking the start of Burmese historiography. ${ }^{7}$ Modern Burma studies, however, began with the first wave of European contacts during the sixteenth and seventeenth centuries. In their ship's logs and private journals, these early explorers described societies and cultures that were quite different from any encountered before. As foreign contacts grew, and Burma came to be visited more often by traders, officials and missionaries, these accounts grew in number. They also became more comprehensive and reflective. ${ }^{8}$ Europeanand particularly British-writings on Burma greatly increased during the nineteenth century, with the colonisation of the country by the United Kingdom (UK).

${ }^{6}$ See, for example, Michael Aung-Thwin, 'Spirals in Early Southeast Asian and Burmese History', Journal of Interdisciplinary History, Vol. 21, No. 4 (Spring 1991), pp. $575^{-602 .}$

7 Tin Ohn, 'Modern Historical Writing in Burmese, 1724-1942', in D. G. E. Hall (ed.), Historians of South-East Asia (Oxford University Press, London, 1961), pp. 85-93.

${ }^{8}$ See, for example, Michael Symes, Account of an Embassy to the Kingdom of Ava sent by the Governor-General of India in the year I 795 (Bulmer and Co., London, 1800) and Father [Vincentius] Sangermano, A Description of the Burmese Empire, Compiled chiefly from Burmese documents, fifth edition (Susil Gupta, London, 1966). Father Sangermano's book was first published in Rome in 1833 . Also important is Henry Yule's 1856 report, later published as Narrative of the Mission to the Court of Ava in 1855 , Together with the Journal of Arthur Phayre (Oxford University Press, London, 1968). 
During the main period of British rule, from $185^{2}$ to 1942 , Burma studies flowered as intellectuals, scholar-bureaucrats and missionaries published learned works on a wide range of topics. Usually employing contemporary research and analytical methodologies, they discovered and described many hitherto unrecorded facets of Burmese archaeology, history, geography, anthropology and natural science. Religious and linguistic subjects also received considerable attention. Most authors lived in Burma for lengthy periods and many learnt the local languages, characteristics that lent their writings greater depth and authenticity. Of particular note in this regard is The Burman: His Life and Notions by the British civil servant J. G. Scott ('Shway Yoe'), which remains a classic description of traditional Burmese life and culture. $^{9}$

A number of other important books were published during this period. For example, American Baptist missionary Adoniram Judson published the first Burmese-English dictionary in $1852 .{ }^{10}$ In 1883 Arthur Phayre, Britain's Chief Commissioner in Burma from 1862 to 1867 , published the first continuous history of the country in a European language. ${ }^{11}$ This pioneering work was followed in 1925 by G. E. Harvey's History of Burma, which drew on sources not available to Phayre and 'set out to describe the histories, art and literature of the pre-colonial kingdoms in Burma'. ${ }^{12}$ With publication in $193^{8}$ of his seminal study, An Introduction to the Political Economy of Burma, J. S. Furnivall began what was to become a distinguished career as a scholar of Burma and Britain's colonial administration. ${ }^{13}$ Another figure worth mention here is Gordon Luce. With Pe Maung Tin, he

${ }^{9}$ J. G. Scott ('Shway Yoe'), The Burman: His Life and Notions (Macmillan and Co., London, 1882). See also H. G. Trager, Burma Through Alien Eyes: Missionary Viewes of the Burmese in the Nineteenth Century (Asia Publishing House, Bombay, 1966).

${ }^{10}$ Judson's Burmese-English Dictionary, revised and enlarged by R. G. Stevenson and F. H. Eveleth (Baptist Board of Publications, Rangoon, 1986).

${ }^{11}$ Arthur P. Phayre, History of Burma, including Burma Proper, Pegu, Taungu, Tenasserim and Arakan, from the Earliest Time to the End of the first War with British India, third edition (Augustus Kelley, New York, 1969).

${ }^{12}$ G. E. Harvey, History of Burma: From the Earliest Times to Io March I 824 , The Beginning of the English Conquest, second edition (Frank Cass and Co., London, 1967). See also Alyssa Phillips, 'Romance and Tragedy in Burmese History: A Reading of G. E. Harvey's The History of Burma', SOAS Bulletin of Burma Research, Vol. 3, No. 1 (Spring 2005).

${ }^{13}$ J. S. Furnivall, An Introduction to the Political Economy of Burma (Burma Book Club, Rangoon, 1938). See alsoJ. S. Furnivall, 'The Fashioning of Leviathan: The Beginnings of British Rule in Burma', The Journal of the Burma Research Society, Vol. 29, No. 1 (April 1939), pp. 3-137. 
published Inscriptions of Burma between 1933 and 1939, and became a major figure in Burma scholarship. ${ }^{14}$

In addition, much useful research appeared as official reports and gazetteers. The latter constituted a massive project that resulted, between 1911 and 1935, in the publication of detailed descriptions of all 43 administrative districts in the country, covering such subjects as history, inhabitants, agriculture, minerals, trade, communications, education and administration. Some shorter papers, mainly on historical, geographical and ethnographic issues, appeared in the journal of the Calcutta Branch of the Royal Asiatic Society. ${ }^{15}$ A few articles relating to Burma could also be found in the Journal of the Siam Society, which began in 1904. By far the largest number of scholarly articles, however, was published by the Burma Research Society, which was founded in 1910. Its aims were 'the investigation and encouragement of Art, Science and Literature in relation to Burma and neighbouring countries'. ${ }^{16}$ The Journal of the Burma Research Society was the first peer-reviewed academic publication devoted to Burma studies.

The literature on Burma was swollen by numerous memoirs and accounts of travel around the picturesque colony by visiting foreigners. These publications were largely personal and descriptive, but sometimes they contained valuable information and helpful insights. ${ }^{17}$ Also, in the opinion of one observer:

Almost more valuable than their words are the superb illustrations to be found in many of these books, especially the sketches and watercolour paintings of places, buildings, fashions no longer to be seen $[\mathrm{sic}] .{ }^{18}$

${ }^{14}$ G. H. Luce and Pe Maung Tin, Inscriptions of Burma, 2 vols. (Oxford University Press, Oxford, 1933-39). See also G. H. Luce, Old Burma: Early Pagan (New York University, New York, 1969-7o) and G. H. Luce, Phases of Pre-Pagan Burma: Languages and History, 2 vols. (Oxford University Press, Oxford, 1985).

${ }^{15}$ Founded in 1784 as the Asiatic Society of Bengal, it became the Calcutta Branch of the Royal Asiatic Society after the latter was founded in London in 1829 .

${ }^{16}$ Before closing in 1977 , the Society published 59 volumes, consisting of 136 journals and more than 13 oo articles. P. M. Herbert, Burma (Clio Press, Oxford, 1988), p. 255 .

17 See, for example, G. W. Bird, Wanderings in Burma (Simpkin, Marshall, Hamilton, Kent and Co., London, 1897); V. C. S. O'Connor, The Silken East: A record of life and travel in Burma (Hutchinson, London, 1904) and Maurice Collis, Trials in Burma (Faber, London, 1938). See also S. L. Keck, 'Picturesque Burma: British Travel Writing 18901914', Journal of Southeast Asian Studies, Vol. 35, No. 3 (October 2004), pp. 387-414.

18 A. J. Allott, 'Burma', in Alastair Dingwall (ed.), Traveller's Literary Companion to South-east Asia (In Print, Brighton, 1994), p. 17. 
All these works were influential in shaping popular perceptions of Burma in places like Europe and the United States.

Scholarly attention to Burma was given a major fillip by the Second World War, when the China-Burma-India Theatre assumed considerable strategic importance. ${ }^{19}$ Following the Japanese invasion of Burma in late $194^{1}$ and early 1942, there was a sudden demand among the Allies for detailed information about the country and its people. Geographers, geologists, historians, economists, anthropologists and others with specialised expertise were enlisted to help prepare the vast number of maps, briefing papers and other documents needed for military planning and operations. ${ }^{20}$ There was also an urgent need for background material on Burmese society and culture to prepare the returning Allied Forces for their expected contacts with the local inhabitants. ${ }^{21}$

Much of this activity took place in specialised units dealing with military intelligence, logistics and operations. Related work was also done in agencies such as the British Inter-Services Topographical Department and the US Office of Strategic Services. Some new research, however, was contracted out to scholars at academic institutions, particularly in the US, in an attempt to harness the full intellectual resources of the Allied countries to the war effort. The results of this research were often restricted, but some officially endorsed publications were released to the public, either during or shortly after the war. ${ }^{22}$ There was also a major effort, through dedicated 'area studies' and language training programs, to produce,

${ }^{19}$ Vice Admiral the Earl Mountbatten of Burma, South-East Asia 1943-1945: Report to the Combined Chiefs of Staff by the Supreme Allied Commander, second impression (English Book Store, New Delhi, 1960). Also useful is Louis Allen, Burma: The Longest War, I94 I-I945 (Dent and Sons, London, 1984) and Julian Thompson, The Imperial War Museum Book of the War in Burma, 1942-1945: A Vital Contribution to Victory in the Far East (Sidgwick and Jackson, London, 2002).

${ }^{20}$ W. B. G. Balchin, 'United Kingdom Geographers in the Second World War: A Report', The Geographical Journal, Vol. 153 , No. 2 (July 1987), pp. 159-18o and K. H. Stone, 'Geography's Wartime Service', Annals of the Association of American Geographers, Vol. 69, No. 1 (March 1979), pp. 89-96.

${ }^{21}$ See, for example, Burma During the Japanese Occupation, 2 vols. (Intelligence Bureau, Government of Burma, Simla, 1943-44).

${ }^{22}$ See, for example, H. G. Deignan, Burma-Gateway to China, Smithsonian Institution War Background Studies No. 17 (Smithsonian Institution, Washington DC, 1943) and Geoffrey Gorer, The Burmese Personality (mimeograph, Institute for Inter-Gultural Relations, New York, 1943). Also of interest is J. L. Christian, Modern Burma: A Survey of Political and Economic Development (University of California Press, Berkeley, 1942), re-released as Burma and the Japanese Invader (Thacker and Co., Bombay, 1945). 
as quickly as possible, linguists and other specialists on Burma who could meet the immediate needs of the armed forces, both in rear echelon positions and the front line. ${ }^{23}$

After the war ended, many of these area studies programs were not only continued, but were expanded to include a greater emphasis on scholarship and research. Particularly influential in this regard was a report prepared in the US by Robert Hall for the Social Science Research Council, in $1948 .^{24}$ This effort was initially seen as part of the US post-war liberal democratic project, but was also justified by the growing strategic competition between the West and what was perceived to be a global communist menace. Most funding was channelled into academic programs that focused on countries and regions of greatest strategic interest, notably the Soviet Union, China and Eastern Europe. Some, however, was directed towards Southeast Asia, including Burma. The subjects studied under these programs varied widely, but usually included the political, historical, economic and social problems of specific countries and regions. ${ }^{25}$

\section{Burma Studies After Independence}

After Burma regained its independence from the UK in January 1948, the fledgling government of Prime Minister U Nu was immediately preoccupied with internal security and a wide-ranging economic recovery program. It also adopted a strictly neutral foreign policy and eschewed any involvement in the developing Cold War between the superpowers. Burma thus did not demand the same kind of official attention or funding as did other, potentially hostile, Asian states, like China or North Korea. However, there was a strong perception

${ }^{23}$ In 1940 and 1941, the US Army commissioned practical handbooks, teaching grammars and vocabularies on several 'strategic languages'. W. S. Cornyn produced Spoken Burmese for the US War Department (later published by Henry Holt, New York, 1945). The British could draw on Burmese language texts produced for colonial officers before the war, but they also printed new guides for the armed forces, such as Short Glossary of Burmese (Geographical Section General Staff, War Office, n. p., 1945).

${ }_{24}$ Robert Hall, Area Studies: With Special Reference to Their Implications for Research in the Social Sciences (Committee on World Area Research Program, Social Science Research Council, 1948).

${ }^{25}$ Louis Morton, 'National Security and Area Studies: The Intellectual Response to the Cold War', The Journal of Higher Education, Vol. 34, No. 3, March 1963, pp. 142-7. 
in Washington, shared after 1954 by the Bangkok-based South East Asia Treaty Organisation (SEATO), that Burma was a key regional 'domino' threatened by communist subversion and insurgency. If Burma fell to the communists, so the argument went at the time, Thailand and Indochina would soon follow. ${ }^{26}$ During and after the Korean War, Burma was also seen as a 'back door' to China, through which clandestine military operations could be mounted against the People's Republic. ${ }^{27}$

Burma studies also benefited from the interest shown in the country by US veterans of the Second World War and Korean War, many of whom took advantage of the 1944 Serviceman's Readjustment Act (more commonly known as the GI Bill) to undertake tertiary studies. After 1961, the creation of the US Peace Corps also gave area studies a major boost, as the demand increased for country-specific training, particularly in the local languages. Burma was initially seen as a possible target for US assistance and was visited by the Director of the Peace Corps in 1961. General Ne Win's coup d'etat the following year prevented that initiative from being taken any further, but Burma studies still benefited from the increased attention being given to Southeast Asian programs at US universities, largely to meet the Peace Corps' requirements.

During this period, a number of important studies of Burma appeared. The $195^{\circ}$ s and 1960 s saw the publication of a comprehensive survey of the new Union by Hugh Tinker, and major histories of Burma by John Cady, Dorothy Woodman and Frank Trager. All four books soon became standard reference works. ${ }^{28}$ Notwithstanding the internal security problems caused by the country's continuing ethnic and ideological insurgencies, anthropologists like Manning Nash and Melford Spiro were able to conduct extensive field work in Burma, which ultimately led to the publication of several socio-cultural

26 ' 1952 Policy Statement by US on Goals in Southeast Asia', Key Document No.2, The Pentagon Papers, (Bantam Books, Toronto, 1971), p. 28. The eight SEATO members were the US, UK, France, Australia, New Zealand, Thailand, the Philippines and Pakistan.

${ }^{27}$ R. H. Taylor, Foreign and Domestic Consequences of the KMT Intervention in Burma (Southeast Asia Program, Cornell University, Ithaca, 1973).

${ }^{28}$ Hugh Tinker, The Union of Burma: A Study of The First Years of Independence (Oxford University Press, London, 1957); John Cady, A History of Modern Burma (Cornell University Press, Ithaca, 1958); Dorothy Woodman, The Making of Burma (The Cresset Press, London, 1962) and F.N. Trager, Burma: From Kingdom to Republic: A Historical and Political Analysis (Pall Mall, London, 1966). 
studies of Burmese life. ${ }^{29}$ There was also a small but vibrant academic community in post-war Burma, which saw the publication of a number of works by local figures. Some were published in English, or by foreign publishing houses, including works by Maung Maung Pye, Maung Maung and Ba U. ${ }^{30}$

This high level of activity was assisted by the creation of the Rangoon-Hopkins Centre for Southeast Asian Studies, which opened in 1954 to serve the teaching and research needs of Rangoon University and other universities in the region. This was a joint undertaking of the Johns Hopkins University School of Advanced International Studies (SAIS) and Rangoon University. SAIS provided a number of fellowships each year for graduates to study at the Centre. Funding from various US foundations supported other research programs in Burma. A Foreign Area Training Fellowship in 196162, for example, made it possible for John Badgley to study Burma's intellectual elite and a Fulbright Fellowship helped Richard Butwell research a biography of Prime Minister $\mathrm{U} N u{ }^{31}$

After 1962, however, the climate for academic research changed dramatically. On seizing power, Ne Win and his Revolutionary Council immediately set about implementing 'The Burmese Way to Socialism'. In addition to closing parliament and banning all political parties (other than its own), the regime severely curtailed freedom of speech and association. All newspapers, magazines and books were subject to severe censorship. Burmese academics, and academic institutions, were placed under a range of restrictions. Historical studies which re-evaluated colonial approaches to Burma were usually deemed acceptable, but few other works escaped scrutiny. ${ }^{32}$ Through reduced funding and open intimidation, local scholars were encouraged

${ }^{29}$ Manning Nash, The Golden Road to Modernity: Village Life in Contemporary Burma (University of Chicago Press, Chicago, 1965) and M. E. Spiro, Burmese Supernaturalism (Institute for the Study of Human Issues, Philadelphia, 1967).

${ }^{30}$ Maung Maung Pye, Burma in the Crucible (Khittaya Publishing House, Rangoon, 1951); Dr Maung Maung, Burma in the Family of Nations (Djambatan, Amsterdam, 1957) and Ba U, My Burma: The Autobiography of a President (Taplinger, New York, 1959).

${ }_{31}$ See, for example, John Badgley, 'Intellectuals and the National Vision: The Burmese Case', Asian Survey, Vol. 9, No. 8 (August 1969), pp. 598-61 3 and Richard Butwell, U Nu of Burma (Stanford University Press, Stanford, 1963). Also of interest is John Badgley, Politics Among Burmans: A Study of Intermediary Leaders (Centre for International Studies, Ohio University, Athens, 1970).

${ }^{32}$ See, for example, Ni Ni Myint, Burma's Struggle Against Imperialism, I885-I895 (The Universities Press, Rangoon, 1983). Also relevant is Maung Htin Aung, A History of Burma (Columbia University Press, New York, 1967) and Than Tun, 'An Estimation 
to confine themselves to politically 'safe' subjects like Buddhist metaphysics and the Burmese language. Some chose instead to leave Burma and take up positions at Western universities.

The problems encountered by local academics were compounded by the regime's deep suspicion of foreigners and the consequent restrictions placed on the conduct of field work in Burma. The SAIS centre at Rangoon University was closed in 1962 and foreign institutions promoting independent research, like the US-based Asia Foundation, were expelled. Entry visas for foreign academics (and tourists) were initially granted for 24 hours, but even after a relaxation of these controls they were still given only for seven days. Exceptions were made from time to time, usually thanks to the personal intervention of a sympathetic local official, but once again these concessions tended to be in subject areas considered 'safe' by the regime, like archaeology. ${ }^{33}$ As David Steinberg observed in 1981, for many years 'contemporary Burma has been considered terra incognita by many scholars, journalists, and development specialists' ${ }^{34}$

Even so, during the 1970 s and 1980 os foreign scholars made a number of major contributions to modern Burma studies. These included multiple works by Josef Silverstein, Robert Taylor and Steinberg himself. ${ }^{35}$ Of note too was the publication in 1983 of Hugh Tinker's monumental two-volume collection of official documents on constitutional relations between the UK and Burma, from 1944 to $1948 .^{36}$ This period also saw the publication, outside Burma, of autobiographies by two former Burmese leaders and the son of Burma's first President, who was an ethnic Shan. ${ }^{37}$ These and other works were important for the light they shed on a country that, after

of Articles on Burmese History Published in the JBRS, 1910-1970', Journal of the Burma Research Society, Vol. 52, No. 1 (1970), pp. 53-66.

${ }^{33}$ One notable work produced during this period was Pamela Gutman, 'Ancient Arakan: with special reference to its cultural history between the $5^{\text {th }}$ and 11 th centuries', Unpublished PhD thesis, Australian National University, 1977.

${ }^{34}$ D. I. Steinberg, Burma's Road Toward Development: Growth and Ideology Under Military Rule (Westview, Boulder, 1981), p. 1.

35 See, for example, Josef Silverstein, Burma: Military Rule and the Politics of Stagnation (Cornell University Press, Ithaca, 1977); Josef Silverstein, Burmese Politics: The Dilemma of National Unity (Rutgers University Press, New Brunswick, 1980) and R. H. Taylor, Marxism and Resistance in Burma, 1942-1945: Thein Pe Myint's 'Wartime Traveller' (Ohio University Press, Athens, 1984).

${ }^{36}$ Hugh Tinker (ed.), Burma: The Struggle for Independence, I944-1948, 2 vols. (HMSO, London, 1983).

${ }^{37} \mathrm{Ba}$ Maw, Breakthrough in Burma: Memoirs of a Revolution, 1939-1946 (Yale University Press, New Haven, 1968); Nu, U Nu: Saturday's Son (Yale University Press, 
Ne Win's takeover, had retreated into political isolation and economic irrelevancy.

Around the same time, Burma studies began to encounter other problems. It was largely under the rubric of 'area studies' that relatively minor actors on the world stage, like Burma, had been given continuing, albeit modest, attention by officials and academics. While the funds provided were welcome, this was a mixed blessing. As described by one leading proponent in the field:

During and after the war, most area studies were contemporary in orientation and, given the circumstances of their origin, extremely vulnerable to the charge of serving 'non-scholarly' political or military interests. ${ }^{38}$

As time passed, the range of subjects studied under these programs had expanded beyond any direct, practical utility to governments or armed forces, and become more genuinely 'academic' in their orientation. However, the connection between the Cold War and area studies came to be seen as a liability by many scholars in the West. The unease felt by academic institutions increased after it became known that some support for area studies was sourced from US intelligence agencies.

In any case, as the fear of global communism faded, so too did official interest in sponsoring geographically-defined research. There were also challenges from those-in both academia and the large private foundations-who favoured 'cross-boundary' research programs which emphasised the connections between countries, and transnational themes like democratisation and the impact of globalisation, rather than the study of single states or regions. Particularly after the end of the Vietnam War, funding for the study of specific countries, including Burma, declined significantly. The US Defence Department, for example, withdrew support for the regular publication of its foreign area handbooks, which in Burma's case dated back to $1956^{39}$

New Haven, 1975) and Chao Tzang Yawnghwe, The Shan of Burma: Memoirs of a Shan Exile (ISEAS, Singapore, 1987).

${ }^{38}$ Benjamin J. Schwartz, 'Presidential Address: Area Studies as a Critical Discipline', The Journal of Asian Studies, Vol. 4o, No. 1 (November 1980), p. 15.

39 A major study by Frank Trager was published by the Human Relations Area Files in $195^{6}$. Revised and updated versions were published in 1968 and 1971. The latest was F. M. Bunge (ed.), Burma: a country study (American University, Washington DC, 1983). Work was begun on a new edition in the early 1990 , but the project was abandoned due to a lack of funds. 
Starved of funding, and unable to conduct original research in Burma during the 26 years that Ne Win ruled the country, many academics turned elsewhere for subjects to study. Burma studies languished. Between 1965 and 1985 , for example, only 143 doctoral dissertations were written with Burma as their primary focus. ${ }^{40}$ According to a survey conducted by the Wilson Centre in 1986, there were then only 67 Burma specialists (i.e., those claiming fluency in a Burmese language) known to be working in the US, Europe, Russia and Japan. ${ }^{41}$ There were clearly others who did not have that level of linguistic expertise, but the total number of scholars working on Burma was still small. Such was the depth of the problem that, after the 1988 meeting of the US-based Association for Asian Studies (AAS), one observer felt compelled to comment on the 'small band of Burma scholars which gathers every year to lament the state of Burma and Burma studies'. ${ }^{42}$

\section{Burma Studies After 1988}

The climate changed once again in 1988, however, when widespread pro-democracy demonstrations were crushed by the armed forces and Burma was thrust into the world's headlines. The advent of a new military government, with more open economic and foreign policies, and the rise of an indigenous opposition movement led by charismatic Nobel Peace Prize winner Aung San Suu Kyi, have seen much greater attention paid to Burma by governments and international organisations. There has been a resurgence of interest in Burma among foreign scholars, commentators and journalists. There has also been a significant increase in the number of postgraduate students working on Burma in the US and, to a lesser extent, Western

${ }^{40}$ Between 1898 and 1985 , there were 285 dissertations written with Burma as the main focus, 96 in the US, 67 in the Soviet Union, 40 in the UK, 26 in Germany, 14 in India and 12 in France. F. J. Shulman, Burma: An Annotated Bibliographical Guide to International Doctoral Dissertation Research, I898-I985 (University Press of America, Lanham, 1986).

41 'Introduction' in R. A. Morse and H. L. Loerke (eds.), Burma: A Study Guide (The Wilson Centre Press, Washington DC, 1988).

${ }^{42}$ R. H. Taylor, 'Review of Josef Silverstein (ed.), Independent Burma at Forty Years: Six Assessments (Ithaca, 1989)', The Journal of Asian Studies, Vol. 49, No. 3 (August 1990), p. 708 . 
Europe and Australia. ${ }^{43}$ In addition, there has emerged an extensive network of expatriates, exiles and activists determined to keep Burma alive in the minds of the international community.

In some respects, the new military government is even more repressive than the Ne Win regime. Yet, ironically, it has permitted more foreign researchers into the country, and for longer periods. Censorship is still pervasive, and the regime is particularly sensitive about any research focusing on opposition leader Aung San Suu Kyi. ${ }^{44}$ It also remains suspicious of journalists, but the military authorities have granted some academics long-term visas and turned a blind eye to researchers posing as tourists, while conducting surveys of local opinion. A number of new and important studies have appeared since 1988, some based on extensive field work. ${ }^{45}$ Also, due largely to the increased international attention being paid to Burma, there is now more information available about developments in the country that can be used, with appropriate care, in scholarly analyses. ${ }^{46}$

Within Burma itself, the regime has occasionally made attempts to promote an image of academic freedom. This has resulted in the publication of some questionable material, but a number of worthwhile studies (including a few in English) have also emerged. ${ }^{47}$ Since 1995, the Universities Historical Research Centre in Rangoon has held a number of international conferences on social science and humanities

${ }^{43}$ A recent survey revealed that more than 25 students in these countries were writing doctoral theses (in English) on Burma-related issues. Interview, Professor D. I. Steinberg, Washington DC, October 2006.

${ }^{44}$ The regime did, however, allow one of Aung San Suu Kyi's biographers to conduct research in Burma, in the hope that she would write a book that was favourable to the military government. See Barbara Victor, The Lady: Aung San Suu Kyi, Nobel Laureate and Burma's Prisoner (Faber and Faber, Boston, 1998). A more recent biography is Justin Wintle, Perfect Hostage: A Life of Aung San Suu Kyi (Hutchinson, London, 2007). Aung San Suu Kyi's own writings and thoughts have been published in several books, notably Michael Aris (ed.), Freedom From Fear and otherwritings (Viking, London, 1991) and (with Alan Clements), The Voice of Hope (Seven Stories, New York, 1997).

${ }_{45}$ See, for example, Ardeth Maung Thawnghmung, Behind The Teak Curtain: Authoritarianism, Agricultural Policies and Political Legitimacy in Rural Burma/Myanmar (Kegan Paul, London, 2004).

${ }^{46}$ Censorship extends to literary works and even cartoons. See Anna Allott, Inked Over, Ripped Out: Burmese Storytellers and the Censors (PEN American Centre, New York, 1993).

47 See, for example, The 1947 Constitution and The Nationalities, 2 vols. (Universities Historical Research Centre and Innwa Publishing House, Yangon, 1999). 
issues, at which foreign academics have given papers. ${ }^{48}$ The effective collapse of the higher education system in Burma since 1988, however, and the easing of restrictions against leaving Burma, have encouraged many young Burmese intellectuals to seek their fortunes elsewhere. This is a major loss to Burma, and will have a long-term impact on educational standards in the country. It has meant, however, that there is now a new generation of Burmese students and academics in universities around the world, undertaking Burma studies. ${ }^{49}$

For a long time, there were no academic centres outside the country dedicated to Burma studies, although in 1955 the Burma Research Project (BRP) was launched at New York University with the help of the US Army, through the Human Relations Area Files initiative. ${ }^{50}$ The situation changed in 1986, however, when the AAS's Burma Studies Group selected Northern Illinois University (NIU) to be the home of a national Centre for Burma Studies. In addition, in 1996 a Myanmar Studies Centre was opened at Naresuan University in Thailand. In 1999, following a workshop held by the Centre for East and Southeast Asian Studies at Goteborg University in Sweden, a Nordic Burma Studies Group was formed. In 2005 a Centre for Myanmar Studies was established at Manipur University in India.

A number of universities in the US, Western Europe, Russia, Japan and Australia also maintain an interest in Burma, usually as part of broader Southeast Asia programs. ${ }^{51}$

The NIU's Centre for Burma Studies organises biennial conferences, alternately in the US and in regional centres like Singapore, and in most years the Australian National University organises 'Burma Update' conferences, usually in Canberra. Also, occasional meetings sponsored by centres of Burma expertise like Georgetown University in Washington DC, and the Singapore-based Institute of South East Asian Studies (ISEAS), have provided valuable opportunities for

${ }^{48}$ For example, Traditions in Current Perspective: Proceedings of the Conference on Myanmar and Southeast Asian Studies, I5-17 November 1995, Yangon (Universities Historical Research Centre, Yangon, 1996).

${ }^{49}$ See, for example, Matrii Aung Thwin, 'Genealogy of a Rebellion Narrative: Law, Ethnology and Culture in Colonial Burma', Journal of Southeast Asian Studies, Vol. 34 (2003), pp. 393-419.

50 The BRP continued for another 20 years, with funding mainly from the RAND Corporation and private foundations.

${ }^{51}$ A useful catalogue of these centres can be found in J. D. Legge, 'The Writing of Southeast Asian History', in Nicholas Tarling (ed.), The Cambridge History of Southeast Asia (Cambridge University Press, Cambridge, 1992), vol. 1, p. 16. 
students of Burma to exchange information and insights. Some of these conferences have resulted in edited volumes of papers. ${ }^{52}$

There are currently three peer-reviewed journals devoted to Burma studies outside the country. These are The Journal of Burma Studies, published annually by the Burma Studies Centre at NIU, the $S O A S$ Bulletin of Burma Research published twice a year by the School of Oriental and African Studies (SOAS) in London and Burma Economic Watch (BEW), which is published periodically on the internet by the Economics Department of Macquarie University in Australia. ${ }^{53}$ Inside Burma, the Myanmar Historical Commission (MHC) regularly publishes the mixed-language Myanmar Historical Research Journal. It occasionally accepts articles by foreign scholars but, like all other publications in Burma, it is subject to censorship by the regime. ${ }^{54}$

It is also important to note the contributions made to Burma studies by observers outside the formal confines of the Academy. Journalists and freelance authors like Bertil Lintner and Martin Smith have not only provided valuable information and analyses about Burma, particularly since 1988 , but they have also written major works based on extensive field work and direct personal experience. ${ }^{55}$ Without their efforts, a number of more academic studies would have been difficult to write. In addition, over the years Burma studies have benefited from the knowledge and views of numerous officials, aid workers, activists and volunteers. While their research has rarely appeared in recognised academic journals, and their publications are not usually included in lists of the academic literature, many of these works provide helpful accounts of current conditions in Burma. ${ }^{56}$

Since Independence, numerous journalists, travel writers and tourists have visited Burma and left accounts of their experiences. As

${ }^{52}$ See, for example, Trevor Wilson (ed.), Myanmar's Long Road to National Reconciliation (Asia Pacific Press, Canberra, 2006).

${ }^{53}$ The BEW can be found at <http://www.econ.mq.edu.au/burma_economic watch>

${ }^{54}$ See, for example, Andrew Selth, 'Australian Contacts with Colonial Myanmar, 1886-1947', Myanmar Historical Research Journal, No. 6 (December 200o), pp. 44-55.

${ }^{55}$ Bertil Lintner, Outrage: Burma's Struggle for Democracy (Far Eastern Economic Review, Hong Kong, 1989); Bertil Lintner, The Rise and Fall of the Communist Party of Burma (CPB) (Cornell University, Ithaca, 1990); Bertil Lintner, Burma in Revolt: Opium and Insurgency Since I948 (Silkworm, Chieng Mai, 1999) and Martin Smith, Burma: Insurgency and the Politics of Insurgency (Zed, London, 1999).

${ }^{56}$ While they have their own agendas, independent NGOs such as the Karen Human Rights Group, Human Rights Watch, Amnesty International and Global Witness have all published useful works on recent developments in Burma, particularly in the areas dominated by the country's ethnic minorities. 
did various itinerants during the colonial period, some have provided useful information and perceptive observations about developments in the country and around its borders. ${ }^{57}$ Also, a few adventurers have travelled to parts of Burma where foreigners were usually not permitted to go, or where they had not been seen for many years. ${ }^{58}$

As a discreet field of scholarly endeavour, Burma studies has experienced something of a revival since 1988 , but it still occupies only a small part in the wider field of Asian studies. Also, like other area studies programs, it suffers from a range of criticisms levelled against it by practitioners in the more established and 'scientific' disciplines. In some respects, this has not been a serious problem, but it has probably had an adverse impact on levels of funding and the acceptability of Burma as a legitimate subject for academic research at universities and other tertiary institutions.

\section{Disciplinary Emphases in Burma Studies}

Academic publications on Burma produced since the Second World War can be roughly divided into four social science disciplines: history, political science, economics and anthropology. As always with such arbitrary divisions, there is some overlap between these categories, but these have been the disciplinary approaches through which most scholars have attempted to understand and explain modern Burma.

Not surprisingly, the largest proportion of scholarly books and articles on Burma that have appeared since 1945 can be broadly classed as history. In various guises, be it prehistory, cultural history, intellectual history, military history or modern history, these works cover a range of subjects from the fall of the ancient Pyu civilisation and the rise of the early Burmese kingdoms, through Burma's 'golden period' of consolidation and expansion in the seventeenth century, to the British colonial period that formally began in $1826 .{ }^{59}$ As might

${ }^{57}$ A selection might include Norman Lewis, Golden Earth: Travels in Burma (Jonathan Cape, London, 1952); Andrew Marshall, The Trouser People: A Story of Burma-In the Shadow of the Empire (Counterpoint, Washington DC, 2002) and Emma Larkin, Secret Histories: Finding George Orwell in a Burmese Teashop (John Murray, London, 2004).

${ }^{58} \mathrm{See}$, for example, Bertil Lintner, Land of Jade: A Journey from India through Northern Burma to China (White Orchid, Bangkok, 1996); Shelby Tucker, Among Insurgents: Walking Through Burma (Radcliffe Press, London, 200o) and Edith Mirante, Down The Rat Hole: Adventures Underground on Burma's Frontiers (Orchid Press, Bangkok, 2005).

${ }^{59}$ Notable works in this category include V. B. Lieberman, Burmese Administrative Cycles: Anarchy and Conquest, I 580-I 760 (Princeton University Press, Princeton, 1984); 
be expected, given the dominant role of Europeans in Burma during the Second World War, numerous histories and memoirs have been published covering the $1939-45$ period. ${ }^{60}$ In recent years, there have been a number of important works in English produced by Westerntrained Burmese scholars, looking at their country's history from an indigenous perspective. ${ }^{61}$

Closely related to these historical studies is a relatively large body of work on Burma's political development since Independence in 1948 . These include exercises in political biography, political economy and political culture. Some articles and books have analysed Burma's brief experiment with democracy from 1948 to 1962 , and the role of Buddhism in Burmese political life. ${ }^{62}$ Most works in this category, however, look at politics in Burma since the 1962 military coup. This research has itself evolved over the past 45 years. Broadly speaking, there was an initial focus on the role of the Burmese armed forces in politics, and the Ne Win regime's idiosyncratic socialist ideology. ${ }^{63}$ Over the years, attention has also been paid to Burma's political identity and political culture. ${ }^{64}$ Since 1988 , there has been a greater emphasis on comparative politics, with studies of local political institutions and the implications of a possible transition from a military dictatorship to a 'guided democracy'. ${ }^{65}$

Michael Aung Thwin, Pagan: The Origins of Modern Burma (University of Hawaii Press, Honolulu, 1985) and M. W. Charney, Powerful Learning: Buddhist Literati and the Throne in Burma's Last Dynasty, I752-I885 (University of Michigan, Ann Arbor, 2006).

${ }^{60}$ Obvious examples include William Slim, Defeat Into Victory (Cassell, London, 1956); and G. M. Fraser, Quartered Safe Out Here: A Recollection of the War in Burma (Harvill, London, 1992).

${ }^{61}$ These works include Thant Myint-U, The Making of Modern Burma (Cambridge University Press, Cambridge, 2001) and Michael Aung Thwin, The Mists of Ramanna: The Legend That Was Lower Burma (University of Hawaii Press, Honolulu, 2005). See also Ni Ni Myint, 'Myanmar Historiography Since 1945', in Abu Talib Ahmad and Tan Liok Ee (eds.), New Terrains in Southeast Asian History (Singapore University Press, Singapore, 2003), pp. 123-140.

${ }^{62}$ See, for example, E. Sarkisyanz, Buddhist Backgrounds of the Burmese Revolution (Martinus Nijhoff, The Hague, 1965) and D. E. Smith, Religion and Politics in Burma (Princeton University Press, Princeton, 1965).

${ }^{63}$ For a useful survey of this period see R. H. Taylor, 'An Undeveloped State: The Study of Modern Burma's Politics', in J. G. Taylor and Andrew Turton (eds.), Sociology of 'Developing Societies': Southeast Asia (Monthly Review Press, New York, 1988), pp. $33-47$.

${ }^{64}$ See, for example, Lucien Pye, Politics, Personality and Nation Building: Burma's Search for Identity (Yale University Press, New Haven, 1962) and Maung Maung Gyi, Burmese Political Values: The Socio-Political Roots of Authoritarianism (Praeger, New York, 1983).

${ }^{65}$ Three books by David Steinberg illustrate this trend: D. I. Steinberg, Burma; A Socialist Nation of Southeast Asia (Westview Press, Boulder, 1987), D. I. Steinberg, 
Perhaps due to Burma's political isolation before 1988, its autarkic economic ideology, strictly neutral foreign policies and relative insignificance in world affairs, there have only been three in-depth academic studies of Burma's foreign relations and its place in the wider international community ${ }^{66}$ There have been even fewer works in English, by Burmese scholars. ${ }^{67}$ The dramatic policy shift under the new military regime, which saw Burma join the Association of South East Asian Nations (ASEAN) in 1997, and develop much closer relations with its neighbours, has sparked greater scholarly interest. The number of articles and books dealing with Burma's bilateral relations with individual countries is steadily growing, although there is still a pressing need for a detailed study of Burma's relations with China. ${ }^{68}$ Since 1997, Burma has also been included (albeit often nominally) in broad studies of ASEAN. Generally speaking, however, international relations is not a field in which Burma has figured prominently.

Nor, despite its important geo-strategic position and numerous long-running insurgencies, has Burma been a serious factor in contemporary security studies. Over the past 20 years, only a small number of scholars outside the country have attempted to examine Burma's threat perceptions, defence policies and military security. Robert Taylor, Tin Maung Maung Than, Desmond Ball and Maung Aung Myoe have published on these and related subjects. ${ }^{69}$ Mary

Burma: The State of Myanmar (Georgetown University Press, Washington DC, 2001) and D. I. Steinberg, Turmoil in Burma: Contested Legitimacies in Myanmar (EastBridge, Norwalk, 2006). See also Tin Maung Maung Than, State Dominance in Myanmar: The Political Economy of Industrialization (ISEAS, Singapore, 2007).

${ }^{66}$ W. G. Johnstone, Burma's Foreign Policy: A Study in Neutralism (Harvard University Press, Cambridge, 1963); Chi-shad Liang, Burma's Foreign Relations: Neutralism in Theory and Practice (Praeger, New York, 1990) and Jurgen Haacke, Myanmar's Foreign Policy: Domestic influences and international implications, (International Institute for Strategic Studies, London, 2006).

${ }^{67}$ See, however, Than Han, Common Vision: Burma's Regional Outlook, Occasional Paper (Institute for the Study of Diplomacy, Georgetown University, Washington DC, 1988).

${ }^{68}$ See, for example, Maung Aung Myoe, Neither Friend Nor Foe: Myanmar's Relations With Thailand Since 1988: A View From Yangon, (Institute of Defence and Strategic Studies, Nanyang Technological University, Singapore, 2002); Renaud Egreteau, Wooing the Generals: India's New Burma Policy (Centre de Sciences Humaines, New Delhi, 2003); and Donald Seekins, Burma and Japan Since I940: From 'Co-Prosperity' to 'Quiet Dialogue' (Nordic Institute of Asian Studies, Copenhagen, 2007).

${ }^{69}$ See, for example, the chapters by Tin Maung Maung Than in Muthiah Alagappa (ed.), Asian Security Practice: Material and Ideational Influences (Stanford University Press, Stanford, 1998) and Muthiah Alagappa (ed.), Military Professionalism in 
Callahan has written about the early days of the armed forces, focusing on their role in state building. ${ }^{70}$ This author has published two books examining Burma's armed forces as a military institution and a number of works that examine Burma's place in the contemporary strategic environment. ${ }^{71}$ As transnational issues have become more important, and the accepted definition of security has expanded, greater attention has been devoted to human security problems in Burma. ${ }^{72}$ Even so, the total body of work in the field of security studies remains small.

Despite the difficulty of obtaining reliable data, there have been a number of major publications that examine Burma's economy and its wider impact, both before and after the 1962 military coup. ${ }^{73}$ Burma is rich in natural resources, and before the Second World War was both an oil producer and the largest rice exporter in the world. Yet, Burma's economy suffered greatly during the war and was not helped to recover by the failure of Ne Win's socialist policies. In 1987, the United Nations officially designated Burma as one of the least developed countries in the world. This decline in Burma's fortunes, and the impact of the 'open door' economic policies introduced by the new military regime in 1989 , has attracted considerable scholarly interest. ${ }^{74}$ The discovery of rich natural gas reserves off Burma's coast has important implications for the country's long-term prosperity,

Asia: Conceptual and Empirical Perspectives (East-West Centre, Honolulu, 2001). Also relevant is Desmond Ball, Burma's Military Secrets: Signals Intelligence (SIGINT) from the Second World War to Civil War and Cyber Warfare (White Lotus, Bangkok, 1998).

${ }^{70}$ M. P. Callahan, Making Enemies: War and State Building in Burma (Cornell University Press, Ithaca, 2003).

${ }^{71}$ Andrew Selth, Transforming the Tatmadaw: The Burmese Armed Forces Since 1988 (Strategic and Defence Studies Centre, Australian National University, Canberra, 1996); Andrew Selth, Burma's Armed Forces: Power Without Glory (EastBridge, Norwalk, 2002); and Andrew Selth, Burma's North Korean Gambit: A Challenge to Regional Security? (Strategic and Defence Studies Centre, Australian National University, Canberra, 2004).

${ }^{72}$ Tin Maung Maung Than, 'Mapping the Contours of Human Security Challenges in Myanmar', in N. Ganesan and Kyaw Yin Hlaing (eds.), Myanmar: State, Society and Ethnicity (ISEAS, Singapore, 2007), pp. 172-218.

${ }^{73}$ An early work was J. R. Andrus, Burmese Economic Life (Stanford University Press, Stanford, 1948). For a study of Burma's economic geography see Michael Adas, The Burma Delta: Economic Development and Social Change on an Asian Rice Frontier, I 852-I94I (University of Wisconsin Press, Madison, 1974).

${ }^{74}$ See, for example, Mya Than and J. L. H. Tan (eds.), Myanmar Dilemmas and Options: The Challenge of Economic Transition in the I 990 (ISEAS, Singapore, 1990); Mya Maung, The Burma Road to Poverty (Praeger, New York, 1991) and Myat Thein, Economic Development of Myanmar (ISEAS, Singapore, 2004). 
political stability and foreign relations, and this development too is likely to receive increased attention. ${ }^{75}$

There have also been numerous works that are broadly sociological and anthropological in nature, focusing on Burma's rich and diverse societies, religions, languages and cultures. Such studies have long been popular among Burma scholars, keeping alive a tradition begun by colonial administrators and building on major works by researchers like Edmund Leach. ${ }^{76}$ A number of scholars have examined the critical role of Buddhism in Burmese society. ${ }^{77}$ Burma's art, crafts and, to a lesser extent, its modern literature have also received some attention. Since 1988, there has been an increased demand for publications in these fields, ranging from scholarly works to large format 'coffee table' books. While usually designed for the more popular market, some of the latter works have made important contributions to the wider understanding of Burmese society and culture. ${ }^{78}$

A related theme, particularly since 1988, has been the plight of Burma's ethnic and religious minorities. Numerous publications have documented the brutality of the regime's military campaigns from 1962 to the present day, and the consequent problems of internally displaced people and refugees. ${ }^{79}$ Other works have covered the regime's attempts to impose the dominant ethnic Burman Buddhist culture on the smaller ethnic groups, usually under the guise of 'economic development', and in the name of national unity and social stability. ${ }^{80}$ Over the past 19 years, many of the publications covering

75 Tin Maung Maung Than, 'Myanmar's Energy Sector: Banking on Natural Gas', in Southeast Asian Affairs 2005 (ISEAS, Singapore, 2005), pp. 257-289 and Marie Lall, 'Indo-Myanmar Relations in the Era of Pipeline Diplomacy', Contemporary Southeast Asia, Vol. 28, No. 3, (December 2006), pp. 424-446.

${ }^{76}$ E. R. Leach, Political Systems of Highland Burma: A Study of Kachin Social Structure (London School of Economics and Political Science, London, 1954).

77 See, for example, Juliane Schober, 'Venerating the Buddha's Remains in Burma: From Solitary Practice to the Cultural Hegemony of Communities', Journal of Burma Studies, Vol. 6 (2001), pp. 111-40; and Juliane Schober, 'Buddhist Just Rule and Burmese National Culture: State Patronage of the Chinese Tooth Relic in Myanmar', History of Religions, Vol. 36 , No. 3 (February 1997), pp. $218-43$.

78 These include Sylvia Fraser-Lu, Burmese Crafts: Past and Present (Oxford University Press, Kuala Lumpur, 1994) and Donald M. Stadtner, The Art of Burma: New Studies (Marg, Mumbai, 1999).

79 Ashley South, Burma: The Changing Nature of Displacement Crises (Refugee Studies Centre, Oxford, 2007) and H. J. Lang, Fear and Sanctuary: Burmese Refugees in Thailand (Cornell, Ithaca, 2002).

${ }^{80}$ M. P. Callahan, Political Authority in Burma's Ethnic Minority States: Devolution, occupation and coexistence (East-West Centre, Washington DC, 2007). For another view, see Development by Decree: The politics of poverty and control in Karen State (Karen Human 
these issues have been produced by independent non-government organisations and activist groups. In strict academic terms, these 'grassroots' reports are of mixed quality, but they are often quite informative. A number of scholarly studies of Burma's ethnic and religious communities, both inside and outside the country, have also appeared. ${ }^{81}$

\section{Burma Studies and the Academy}

In surveying all these publications over the years, it is possible to discern a number of broad characteristics. Firstly, most Burma scholars, particularly since 1988, seem to have approached their work with the aim of applying their academic training and skills to Burma itself, or at least to a set of intellectual problems specifically related to Burma, rather than seeing their research as an exercise in a particular academic discipline. In Katzenstein and Okawara's words, it is 'problem-driven research' rather than 'approach-driven analysis'. ${ }^{82}$ Largely as a consequence, even when focusing on quite specific issues modern Burma scholars have tended to take an inter-disciplinary view, rather than approach them through the traditional departments into which academic institutions are usually organised.

To an extent, this approach reflects a broad trend in the study of Southeast Asia since the Second World War. For example, modern historians of Burma have gone well beyond the largely descriptive, fact-based accounts of earlier years, and drawn on other social science disciplines to produce balanced and comprehensive analyses. The boundaries between history and political science, in particular, have

Rights Group, Mae Sot, 2007). 'Burman' is used to refer to the dominant ethnolinguistic group in Burma.

${ }^{81}$ See, for example, Ashley South, Mon Nationalism and Civil War in Burma: The Golden Sheldrake (Routledge Curzon, London, 2003); Ashley South, 'Karen Nationalist Communities: The "Problem" of Diversity', Contemporary Southeast Asia, Vol. 29, No. 1 (2007), pp. 55-76; and Curtis Lambrecht, 'Burma (Myanmar)' in Greg Fealy and Virginia Hooker (eds.), Voices of Islam in Southeast Asia: A Contemporary Sourcebook (ISEAS, Singapore, 2006). Two recent contributions to this field are Mikael Gravers (ed.) Exploring Ethnic Diversity in Burma (Nordic Institute of Asian Studies, Copenhagen, 2007) and Martin Smith, State of Strife: The Dynamics of Ethnic Conflict in Burma (EastWest Centre, Washington DC, 2007).

${ }^{82}$ Peter J. Katzenstein and Nobuo Okawara, 'Japan, Asia-Pacific Security, and the Case for Analytical Eclecticism', International Security, Vol. 26, No. 3 (Winter 2001O2), p. 183 . 
become blurred, in what one historiographer has dubbed 'the Cornell tradition'. ${ }^{83}$ Other disciplines have been affected too. Few descriptions of modern Burma, for example, do not include some coverage of economic and sociological factors. This multi-disciplinary approach stems in part from a wish to reflect the totality of developments taking place in Burma, but it also springs from the inter-related nature of many of the problems the country currently faces.

It is not possible, for example, for a political scientist to examine the development of Burma's political institutions or its gradual progress towards a new, ostensibly 'democratic', government, without also considering the country's modern history, its political culture, its economic problems, the collapse of its civil society or its ethnic and religious diversity. ${ }^{84}$ Similarly, if looking at Burma's international relations, a specialist would need to consider a range of diverse factors beyond Burma's contacts with other countries and multilateral organisations. Its colonial experience, past economic problems, social structure and military indoctrination programs are also important. To a greater or lesser degree, all are inter-connected and need to be taken into account in any research on Burma, regardless of any formal divisions that may exist between academic disciplines.

This phenomenon illustrates another trend. Following from the intrinsic fascination with Burma as a subject for research and analysis, and reflecting the complexity of the challenges the country faces, is the relatively large number of scholarly works that aim to describe and, in many cases, help solve Burma's seemingly intractable problems.

After Independence, the $\mathrm{U} \mathrm{Nu}$ Government actively sought foreign expertise and advice. ${ }^{85}$ Since 1962 , the military regime has consistently resisted such interventions - well meaning or otherwisebut this seems only to have encouraged the production of articles and books that examine the tragedy that is Burma's continuing military dictatorship, with its lack of political freedoms, dire economic and social problems, and pariah status in the international arena. The creation of a new military government in 1988, in particular,

${ }^{83}$ Legge, 'The Writing of Southeast Asian History', vol. 1, p. 20. This theme is explored at greater length in J. D. Legge, 'Southeast Asian History and the Social Sciences', in C. D. Cowan and O. W. Wolters, Southeast Asian History And Historiography: Essays Presented to D. G. E. Hall (Cornell University Press, Ithaca, 1976), pp. 388-404.

${ }^{84}$ Kyi May Kaung, 'Theories, Paradigms, or Models in Burma Studies', Asian Survey, Vol. 35, No. 11, November 1995), pp. 1030-41.

85 See, for example, L. J. Walinsky, Economic Development in Burma, I95 I-1960 (Twentieth Century Fund, New York, 1962). 
has resulted in an outpouring of publications-both scholarly and otherwise — that seek to offer advice of different kinds to the regime. ${ }^{86}$ There is also a substantial literature aimed at other governments, arguing the benefits—or otherwise-of various policy approaches towards Burma's military government. ${ }^{87}$

These characteristics have not always found favour with mainstream academics, amongst whom area studies, including Burma studies, are still viewed with suspicion. As the editors of one learned journal noted in 2005:

The last decade has seen intensifying debates about whether area studies constitutes a legitimate field of study in the social sciences. As rational choice, game theoretic, and quantitative methods become more commonplace, scholars who spend years studying the politics of one region in great detail have a harder time justifying their research. ${ }^{88}$

One major problem seems to be simply that area studies lack their own distinctive methodologies or theories, something decried by "disciplinary based, "scientific" critics who value nomothetic approaches more than contextualisation' ${ }^{89}$ There are also cultural critiques developed from the perspective of the humanities. Other academics have expressed concern that area studies, including Burma studies, privilege the contemporary nation state as the elementary unit of analysis, and conceive of artificially defined 'areas' as if they were 'the natural —or at least historically necessary-formations for the containment of differences within and between cultures'. ${ }^{90}$

Scholars like Edward Said have taken this view even further, calling for 'disciplines defined intellectually' over fields that are 'defined canonically, imperially and geographically'. ${ }^{91} \mathrm{He}$ has condemned

${ }^{86}$ See, for example, Christopher Len and Johan Alvin, Burma/Myanmar's Ailments: Searching for the Right Remedy (Silk Road Paper, Johns Hopkins University, Washington DC, 2007).

87 The reports produced by the International Crisis Group (ICG), for example, cover many different aspects of contemporary Burma and are unashamedly policy prescriptive. See, for example, Myanmar: The Politics of Humanitarian Aid, ICG Asia Report No. 32, (ICG, Brussels, 2002) and Myanmar: Sanctions, Engagement or Another Way Forward, ICG Asia Report No. 78, (ICG, Brussels, 2004).

88 'Editors' Introduction', Asian Security, Vol. 1, No. 1 (January 2005), pp. 1-2.

${ }^{89}$ P. J. Katzenstein, 'Area and Regional Studies in the United States', PS: Political Science and Politics, Vol. 34, No. 4, December 2001, p. 789.

${ }^{90}$ V. L. Rafael, 'The Cultures of Area Studies in the United States', Social Text, No. 41, Winter 1994, p. 91. One study accused of reifying the state is R. H. Taylor, The State in Burma (Hurst \& Co, London, 1987).

${ }^{91}$ E. W. Said, Orientalism (Penguin, London, 2003 ), p. 326. 
any approach that sets aside specific parts of the world as distinct entities for study (by implication, by Westerners and those trained in the Western tradition), on the grounds that modern area studies are the linear descendent of discredited 'Orientalist' schools. In the field of Burma studies there have also been accusations that modern academics have-knowingly or unknowingly-perpetuated the prejudices and analytical errors of some colonial era scholars. ${ }^{92}$ Another charge occasionally heard is that, by imposing on Burma a modern, liberal, pluralist paradigm, and writing as if a democracy was always the preferred form of government, Western academics are denying the Burmese their own indigenous cultural norms. ${ }^{93}$

Another rather uncharitable view of area studies, including Burma studies, is that they are useful only because they furnish empirical data to practitioners of more 'scientific' academic disciplines. There is a notion that area specialists are too narrowly focused and thus incapable of engaging in comparative analysis, which is best conducted within a framework of general and widely applicable categorisations. In response to this sort of criticism, Burma has increasingly been included (albeit from a low base) as a case study in comparative works dealing with such broad themes as ethnic conflict, political legitimacy, strategic culture and the role of religion in regional politics. ${ }^{94}$ In addition, there has been a greater emphasis in recent years on crossregional studies that 'seek to blend and incorporate elements from both scientific and humanistic perspectives'. ${ }^{95}$

${ }^{92}$ Manuel Sarkisyanz, Peacocks, Pagodas and Professor Hall: A Critique of the Persisting Use of Historiography as an Apology for British Empire-Building in Burma (Centre for International Studies, Ohio University, Athens, 1972). See also Michael Aung Thwin, Myth and History in the Historiography of Early Burma: Paradigms, Primary Sources, and Prejudices (Ohio University, Athens, 1998) and Michael Adas, 'Imperial Rhetoric and Modern Historiography: The Case of Lower Burma Before and After the Conquest', Journal of Southeast Asian Studies, Vol. 3 (1972), pp. 175-92.

${ }_{93}$ Michael Aung-Thwin, 'Parochial Universalism, Democracy Jihad and the Orientalist Image of Burma: The New Evangelism', Pacific Affairs, Vol. 74, No. 4 (Winter 2001-02), pp. 483-505. See also R. H. Taylor, 'Burma's Ambiguous Breakthrough', Journal of Democracy, Vol. 1, No. 4 (Fall 1990), pp. 62-72.

${ }^{94}$ See, for example, David Brown, The State and Ethnic Politics in Southeast Asia (Routledge, London, 1994); Muthiah Alagappa (ed.), Political Legitimacy in Southeast Asia: The Quest for Moral Authority (Stanford University Press, Stanford, 1995); Ken Booth and Russell Trood (eds.), Strategic Cultures in the Asia-Pacific Region (Macmillan, Houndmills, 1999) and Ian Harris (ed.), Buddhism and Politics in Twentieth Century Asia (Continuum, London, 1999).

${ }^{95}$ Katzenstein, p. 789 . 
Indeed, a criticism of many broad regional or cross-boundary studies has been that they do not sufficiently draw on the specialist Burma expertise that is available. For example, a number of recent works have examined transnational problems in Southeast Asia, such as international terrorism, narcotics trafficking and people smuggling. Some have included case studies of Burma, written by recognised specialists or professionals with direct experience working in Burma. ${ }^{96}$ Other works, however, have been written by subject experts who, not surprisingly, have lacked a detailed knowledge or nuanced understanding of Burma. This has had mixed results. Burma's varied history and complex problems are not well understood by non-Burma specialists. $^{97}$

In any case, Burma has not been completely ignored in studies of broad conceptual issues, such as imperialism, colonialism, nationalism, communism, and militarism. To take just a few examples, Michael Adas included a Burma case study in his 1979 book on protests against the European colonial order, a 2003 reader on decolonisation included a chapter on race and resistance in Burma and Benedict Anderson cited Burma on numerous occasions in Imagined Communities, his book on nationalism. ${ }^{98}$ Burma was also included in a number of early studies of the strategic uses of political violence. ${ }^{99}$ Lucien Pye contributed a chapter on Burma to a study of the role of the armed forces in 'underdeveloped' countries and Moshe Lissak used Burma as a critical case study in his examination of military roles in modernisation. ${ }^{100}$ More recently, Martin Smith discussed Burma

${ }^{96}$ See, for example, Martin Jelsma, Tom Kramer and Pietje Vervest (eds.), Trouble in the Triangle: Opium and Conflict in Burma (Silkworm, Chiang Mai, 2005).

${ }^{97}$ For example, Burma-related issues are managed well in Alan Dupont, East Asia Imperilled: Transnational Challenges to Security (Cambridge University Press, Cambridge, 2001). Less impressive is Zachary Abuza, Militant Islam in Southeast Asia: Crucible of Terror (Lynne Rienner, Boulder, 2003).

${ }^{98}$ Michael Adas, Prophets of Rebellion: Millenarian Protest Movements against the European Colonial Order (Cambridge University Press, Cambridge, 1979); Andrew Selth, 'Race and Resistance in Burma, 1942-1945', in J. D. Le Sueur (ed.), The Decolonisation Reader (Routledge, London, 2003) and Benedict Anderson, Imagined Communities: Reflections on the Origins and Spread of Nationalism, revised edition (Verso, London, 1996).

${ }^{99}$ See the chapters by David Steinberg and Jon Wiant in Lim Joo-Jock and S. Vani, (eds.), Armed Separatism in Southeast Asia (Institute of South East Asian Studies, Singapore, 1984).

${ }^{100}$ L. W. Pye, 'The Army in Burmese Politics', in J. J. Johnson (ed.), The Role of the Military in Underdeveloped Countries (Princeton University Press, Princeton, 1962) and Moshe Lissak, Military Roles in Modernization: Civil-Military Relations in Thailand and Burma (Sage, Beverly Hills, 1976). 
at length in a comprehensive survey of 'political armies' around the world. ${ }^{101}$ In all cases, Burma offered useful illustrative examples of wider issues.

Burma has not often been examined closely in publications exploring more theoretical themes, but there are some notable exceptions. For example, Samuel Huntington used Burma as an example in his early book Political Order in Changing Societies in which he argued that order was an important goal for developing societies, whether or not that order was democratic. ${ }^{102}$ Similarly, Burma figured prominently in Lucian Pye's 1985 study of the cultural dimensions of politics in Asia, John Kane included a chapter about Aung San Suu Kyi in his study of The Politics of Moral Capital, and more recently Stephen McCarthy used Burma as a critical case study in his book on the political theory of tyranny. ${ }^{103}$ Burma's case is in many respects sui generis, but because of its unusual path of political, economic and social development it can offer useful examples to theorists wishing to illustrate broad concepts-including as an exception to a general rule. ${ }^{104}$

More to the point, perhaps, the criticisms levelled at area studies by some academic theorists ignore the fact that every scholar who approaches the study of a country like Burma brings with him or herself-consciously or not-an array of theoretical concepts derived from their own academic training and professional experience. Harking back to Robert Hall's seminal paper on this subject, they are 'dual citizens' with competencies in both an area studies field and in a recognised academic discipline. Also, as Chalmers Johnson has persuasively argued, the examination of particular countries can, by providing detailed case studies, itself add significantly to the conceptual literature. ${ }^{105}$ The fact that they do not reveal universally

101 Martin Smith, 'Army Politics as a Historical Legacy: the experience of Burma', in Kees Koonings and Dirk Kruijt (eds.), Political Armies: The Military and Nation Building in the Age of Democracy (Zed, London, 2002).

${ }^{102}$ Samuel Huntington, Political Order in Changing Societies (Yale University Press, New Haven, 1968).

${ }^{103}$ L. W. Pye, Asian Power and Politics: The Cultural Dimensions of Authority (Belknap Press, Cambridge, 1985); John Kane, The Politics of Moral Capital (Cambridge University Press, Cambridge, 2001) and Stephen McCarthy, The Political Theory of Tyranny in Singapore and Burma: Aristotle and the rhetoric of benevolent despotism (Routledge, London, 2006).

${ }^{104}$ For example, Francis Fukuyama, The End of History and The Last Man (Penguin, London, 1992), p. 85 .

${ }^{105}$ Chalmers Johnson, 'Political Science and East Asian Area Studies', World Politics, Vol. 26, No. 4 (July 1974), pp. $5^{60-75}$. 
valid laws, or lend themselves to conceptual generalisation, does not render them invalid as scholarly exercises.

The obvious answer, as envisaged by Hall in 1947, is a reciprocal, if asymmetrical, relationship between area studies and the disciplines that encourages collaboration rather than competition across academic boundaries. As one scholar has noted, perhaps a little tartly, area studies can nourish the disciplines 'so as to bring them in better touch with the "real world". ${ }^{106}$ Similarly, a familiarity with the arguments of the theoretical schools can bring additional rigour and focus to less structured area studies. Even if this ideal was achieved, however, there would remain the persistent belief in many official and academic circles that developments in Burma are not important in themselves, and cannot offer meaningful insights into events elsewhere. These misconceptions seem to derive, in large part, from a lack of knowledge about Burma, a problem itself stemming from the difficulty of conducting serious research in the country and obtaining reliable data for analysis and comparison.

\section{Contemporary Problems}

Burma has been a closed society since the 1962 military coup, and over the years academic researchers have experienced all the problems associated with that status. Conditions changed noticeably after 1988 , but documentary analysis and field work remain very difficult. ${ }^{107}$

As noted above, the new military government has relaxed visa controls and now permits foreigners to live in Burma for extended periods. It has also eased restrictions on contacts between Burmese citizens and foreigners, particularly in the central parts of the country. However, freedom of speech and association in Burma are still severely curtailed. The government is believed to have spies everywhere. Teachers, civil servants and even members of the

106 Rafael, p. 95.

107 Bruce Swaffield, 'Burma among most oppressive for journalists', The Quill, Vol. 94, No. 3 (April 2006), p. 41. The collapse of the feared Military Intelligence Service in 2004, due to a power struggle within the armed forces, probably contributed to a slightly freer atmosphere in Burma for a period, but since then the regime has introduced a number of additional control measures. US Government Accountability Office, International Organizations: Assistance Programs Constrained in Burma, Report to the Committee on Foreign Affairs, House of Representatives, Washington DC, April 2007 . 
public are required to report any 'disloyal' or 'subversive' behaviour. Criticism of the government can result in long terms of imprisonment. As a consequence, most Burmese are usually too frightened to speak frankly to outsiders about public issues, let alone sensitive matters such as the political role of the armed forces or the country's national security. ${ }^{108}$ Access to modern means of communication-including the internet-is restricted. ${ }^{109}$ Even the possession of an unauthorised fax machine or satellite telephone can result in a lengthy term of imprisonment.

As in all such societies, attempts are made to present a particular image of the country, both to a domestic audience and to the outside world. Government statements thus need careful interpretation and published statistics can rarely be relied upon. Also, there is an official culture of secrecy and obfuscation in Burma, exacerbated by low bureaucratic standards and widespread corruption. ${ }^{110}$ Few officials-civilian or military-are prepared to grant interviews to foreign scholars and, even if they do, they tend to stick closely to the government line. Access to the government or military archives is sometimes granted to selected researchers, but permission is not easy to obtain, even if one can read Burmese-which most foreign academics cannot. ${ }^{11}$ Even Burmese scholars have difficulty gaining access to information that most foreigners would deem to be harmless.

This situation is exacerbated by the opaqueness of the military government itself. Despite occasional claims by informants to 'inside knowledge', the inner workings of the regime are largely unknown to outsiders and even to many inside official circles. Government statements and stories in the state-run news media (including, since 1980, national television) can offer useful clues, but there is little real understanding of how major decisions are reached, and what factors are relevant to particular policy outcomes. This opaqueness extends to the highest levels of government, where many important issues seem

${ }^{108}$ Monique Skidmore, Karaoke Fascism: Burma and the Politics of Fear (University of Pennsylvania Press, Philadelphia, 2004).

${ }^{109}$ See, for example, Internet Filtering in Burma in 2005: A Country Study, found at $<$ http://www.opennetinitiative.net/burma>

110 According to Transparency International, Burma has consistently ranked among the world's most corrupt countries. 'Burma hits new low in corruption', $B B C$ News, 26 September 2007.

${ }^{111}$ Mary Callahan, 'Burmese Research Days: Or, A Day in the Life of a Nearly Extinct Life-Form: A Foreign Researcher in Burma', Southeast Asia Program Bulletin, Cornell University, Spring 1994, pp. 2-4. 
to be decided by individuals, notably regime leader Senior General Than Shwe. Yet the personal views and perceptions of the armed forces leadership are little known by outsiders, and poorly understood. ${ }^{112}$

There is thus a serious dearth of hard data, little verifiable documentary evidence and relatively few well-informed sources of information about current developments. Since 1988 in particular, Burma-watchers have been repeatedly reminded of the limits of their knowledge about a wide range of issues.

For example, there have been at least 13 reasons put forward by officials, academics and journalists to explain why the seat of government was moved from Rangoon to Naypyidaw in late $\mathbf{2 0 0 5}$. None, however, can be viewed as authoritative. Indeed, no one has a clear idea of precisely what prompted the regime to build an expensive new capital, or why it suddenly forced so many public servants to pack up their offices and transfer to Naypyidaw when they did. ${ }^{13}$ To take another example, the Burma studies community does not yet fully understand the many complex factors that led to Lieutenant General Khin Nyunt's extraordinary fall from grace in October 2004 and the collapse of the powerful Directorate of Defence Services Intelligence (DDSI) - this, despite the fact that Khin Nyunt was widely seen as the third most powerful man in the country at the time, and the DDSI was considered by some to be Burma's de facto government.

Indeed, some aspects of Burma studies have come to resemble what was known during the Cold War as Kremlinology-trying to discern the inner workings of the Soviet leadership from such intangible signs as the removal of official portraits, and the placement of officials on the Kremlin balcony during May Day parades in Moscow. ${ }^{114}$ Intelligence agencies, academics and journalists used to play similar games with

112 See, for example, Andrew Selth, 'Burma in a Changing World: Through a Glass Darkly', AQ: Journal of Contemporary Analysis, Vol. 75, Issue 4 (July-August 2003), pp. $15^{-21}$; and Myanmar: The Military Regime's View of the World, ICG Asia Report No. 28 (ICG, Brussels, 2001). Also relevant is R. H. Taylor, 'Burma: Political Leadership, Security Perceptions and Policies', in Mohammed Ayoob and Chai-Anan Samudavanija (eds.), Leadership Perceptions and National Security (ISEAS, Singapore, 1989).

${ }^{113}$ Maung Aung Myoe, The Road to Naypyitaw: Making Sense of the Myanmar Government's Decision to Move its Capital (Asia Research Institute, National University of Singapore, 2006) and Clive Parker, 'Inside Myanmar's Secret Capital', Asia Times, 28 October 2006.

${ }^{114}$ Gustaaf Houtman, Mental Culture in Burmese Crisis Politics: Aung San Suu Kyi and the National League for Democracy (Institute for the Study of Languages and Cultures of Asia and Africa, Tokyo University of Foreign Studies, Tokyo, 1999), p. 26-7. 
China, trying to determine which Communist Party official was in the ascendant, and whose influence was waning, from the lists of Central Committee members published each year in Beijing, and the photographs of Party figures which appeared in state-run newspapers. A great deal of time and energy was expended on such exercises but, as with the shifts in power frequently reported among Burma's senior military leadership, observers rarely knew for certain whether they had managed to read the runes correctly.

Faced with a state-run news media in Burma and in the absence of reliable information and documentary collateral, the knowledge gaps are usually filled by rumour and gossip. This tends to be the daily fare of diplomats, academics, journalists and others in Burma, who are obliged to try and winnow the few grains of truth from the mass of misleading chaff constantly floating around Rangoon and other population centres. ${ }^{115}$ Outside Burma, the large Burmese community and interested activist groups have become adept at using the internet to pass on the latest news and exchange views. Since 1988, a number of expatriate news services have developed, assisted by external funding. ${ }^{116}$ After making allowances for their particular agendas, some websites can be useful sources of information. However, many of the stories about Burma found on the web or in the foreign news media, even when obtained from 'usually reliable sources', cannot be verified and are often speculative-at times even highly imaginative.

Despite having much greater resources to draw upon, the officials of foreign governments can be as much in the dark about developments in Burma as independent researchers. The much vaunted 'technical means' of gathering intelligence, possessed by the great powers, are still unlikely to be able to reveal what is in the heads and hearts of Burma's leaders.

Ironically, developments in areas nearer to Burma's frontiers are sometimes better illuminated. Researchers based in neighbouring countries can freely interview refugees, army deserters, emigrants and traders leaving Burma. They also have access to insurgents and

115 While the Burmese elite and Western business communities in the cities can provide foreign researchers with useful information on a wide range of issues, different perspectives can be gained from the $80 \%$ of Burmese who live in rural villages, or have fled across the country's borders.

116 The three best known expatriate news services are The Irrawaddy (based in Chiang Mai), Mizzima News (based in New Delhi) and the Democratic Voice of Burma (based in Oslo). There are also some smaller groups, like the Shan Herald Agency for News. 
aid workers who regularly operate inside the border. Some foreign journalists and academics have even crossed illegally into Burma to observe conditions at first hand. ${ }^{117}$ Reports based on these interviews and personal experiences tend to be dismissed by some academics as politically biased, or in other ways unreliable. Indeed, some reports suffer from these failings, to a greater or lesser degree. Others, however, still provide valuable information on, and unique insights into, specific developments and trends. Some of these reports have had a major impact on international perceptions of the challenges faced by the Burmese people and have prompted greater official and public interest in the country. ${ }^{18}$

As a result of these and other problems, there has been a considerable volume of material published about Burma since 1988 that needs to be treated with caution. In the absence of hard, verifiable facts, the continuing high demand for news about Burma has led to many unsubstantiated and tendentious reports. In some cases, the propositions put forward are easily dismissed as incredible or at least politically biased. Other suspect stories, however, seem plausible to a public largely ignorant of the complexities of modern Burma, yet willing to believe the worst of the military regime. As a result, a number of myths and misconceptions have taken root in the popular consciousness. Some of these myths have even found their way into scholarly articles and books, giving them a credibility they do not deserve. Once they have achieved that status, they are then recycled in other publications, confusing the issue even further.

To take just a few examples in the security field, there have been repeated claims that Burma possesses chemical and biological weapons, and is now pursuing a nuclear weapons option. The latter belief seems to spring in large part from an assumption that Burma's

${ }^{117}$ For one view of this issue, see Phil Thornton, Restless Souls: Rebels, Refugees, Medics and Misfits on the Thai-Burma Border (Asia Books, Bangkok, 2006).

118 A representative sample might include Dispossessed: Forced Relocation and Extrajudicial Killings in Shan State (Shan Human Rights Foundation, Chiang Mai, 1998); Hand in Glove: The Burma Army and the Drug Trade in Shan State (Shan Herald Agency for News, Chiang Mai, 2006); Poisoned Flowers: The impacts of spiralling drug addiction on Palaung women in Burma (Palaung Women's Association, Mae Sot, 2006); State of Terror: The ongoing rape, murder, torture and forced labour suffered by women living under the Burmese military regime in Karen State (Karen Women's Organisation, Mae Sariang, 2007); Valley of Darkness: Gold Mining and Militarization in Burma's Hugawng Valley (Kachin Development Networking Group, Chiang Mai, 2007); and Turning Treasure Into Tears: Mining, Dams, and Deforestation in Shwegyin Township, Pegu Division, Burma (EarthRights International, Chiang Mai, 2007). 
renewal of diplomatic ties with North Korea in April 2007 is directly connected to the announcement in May 2007 that Burma still planned to acquire a Russian nuclear reactor. According to the same thesis, the chosen delivery vehicle will be North Korean ballistic missiles that, it has been claimed by some activists, have already been delivered to Burma. ${ }^{19}$ There have also been numerous reports that China has established a string of military bases in Burma, which some scholars believe has already become a Chinese client state. ${ }^{120}$ There is no firm evidence to support any of these claims. Until researchers are granted greater access to Burma, however, or the regime becomes more open about its security policies, the actual situation will be difficult to determine.

\section{Divisions Within the Community}

All the problems identified above are compounded by the highly charged atmosphere that, since 1988, has surrounded consideration of most Burma-related issues. In a situation reminiscent of the ideological and academic tensions that blighted Soviet and China studies at the height of the Cold War, Burma studies have become politicised, and highly polarised. Seventeen years after the military government changed the country's name, even the choice of 'Burma' or 'Myanmar' is seen by some observers to denote a partisan political position.

At present, the public debate tends to be dominated by expatriates, foreign activists, specialist academics and regime supporters, many of whom have strong personal views and specific policy agendas. There are those, both inside Burma and outside it, who have an interest in hiding the facts or distorting them to present a particular point of view. Individuals and groups critical of the military government, for example, invariably seek to portray it in the harshest light. For their part, those favouring different interpretations of events or different policy approaches can be quite selective in arguing their case. Both sides are quick to point out the inaccuracies, misperceptions and, in

119 This subject is examined in Andrew Selth, Burma and Nuclear Proliferation: Policies and Perceptions, Regional Outlook No. 12 (Griffith Asia Institute, Griffith University, Brisbane, 2007).

${ }^{120}$ See, for example, Andrew Selth, 'Burma, China and the Myth of Military Bases', Asian Security, Vol. 3, No. 3 (2007), pp. 279-307. 
some cases, double standards of their critics. As might be expected, advocacy groups - of all persuasions - interpret the available material to promote their own causes, even in academic publications. ${ }^{121}$

Nor are governments immune from such considerations. Administrations in democratic countries like the US and UK are sensitive to domestic opinion on issues such as the continuing incarceration of Aung San Suu Kyi, the mistreatment of political prisoners, forced labour and human rights abuses against prodemocracy activists and members of the ethnic minorities. This has led some public figures to highlight the failings of the regime and to ignore, or at least play down, facts deemed harmful to the opposition movement and armed insurgent groups. ${ }^{122}$ Indeed, some politicians appear to have been quite cynical about using the Burma issue to muffle their critics and improve their human rights credentials. Given its very poor record on most issues, and its isolated position internationally, the Burmese regime is an easy target for self-serving criticism.

By the same token, there are other governments, notably those in China, India and Russia, which have been prepared to overlook Burma's long record of human rights abuses to further their own strategic and commercial interests. ${ }^{123}$ Other governments, including a number in the Asia-Pacific region, have responded to such imperatives by being highly selective. Singapore and Thailand, for example, have mixed records on Burma, and since 1988 Australia's policy towards the military regime has fluctuated considerably. ${ }^{124}$ The regime's harsh response to the demonstrations in September 2007 prompted numerous expressions of concern by foreign governments and multilateral institutions, but it also highlighted differences in

${ }^{121}$ See, for example, the controversy over the 'Independent Report for the European Commission', Supporting Burma/Myanmar's National Reconciliation Process: Challenges and Responses, January 2005, found at <http://www.ibiblio.org/obl/docs3/ Independant_Report-Burma_Day.htm>

${ }^{122}$ In a major report, Human Rights Watch was unusual in drawing attention to child soldiers in the ranks of both the Burma Army and armed ethnic groups. My Gun Was As Tall As Me: Child Soldiers in Burma (Human Rights Watch, New York, 2002), pp. $110-57$.

${ }^{123}$ See, for example, Andrew Selth, Burma's Secret Military Partners (Strategic and Defence Studies Centre, Australian National University, Canberra, 200o).

${ }^{124}$ D. I. Steinberg, 'The United States and Its Allies: The Problem of Burma/Myanmar Policy', Contemporary Southeast Asia, Vol. 29, No. 2 (2007), pp. $219-$ 237. 
the international community over ways to respond to the situation in Burma.

These policy differences highlight another phenomenon, namely the gap found between Burma-watchers at different levels of commentary. Diplomats and scholars operating at the more elevated levels of international institutions and the Academy tend to offer broad strategic and philosophical analyses that, in some cases, seem far removed from the harsh realities of life on the ground. ${ }^{125}$ At another level, aid workers, dissidents, activists and other observers closer to daily events in Burma tend to focus on more immediate issues that directly affect its citizens. Both groups have valuable contributions to make but, in the interests of a more comprehensive and balanced understanding of the country and its problems, greater efforts need to be made to bridge the gap between 'elite' and 'subaltern' Burma studies. ${ }^{126}$ This would help ensure that official and academic analyses are grounded in reality, and more focused reports of specific problems take into account wider perspectives.

On a few particularly controversial issues, the international Burma studies community is bitterly divided. Foremost in this category is the question of the best policy approach to be adopted by governments and international organisations. In broad terms, one side favours the imposition of sanctions against the military government, as a way of forcing it to accept the result of the 1990 elections (which were resoundingly won by the opposition parties) and return to the barracks. The other side sees greater value in 'constructively engaging' with the armed forces leadership, in an effort to encourage more liberal policies and, it is hoped, bring about the eventual amelioration of current problems through economic growth and increased space for the development of civil society. ${ }^{127}$ To date, neither approach has been

125 This accusation was at the core of the controversy which erupted after publication of Myanmar: New Threats to Humanitarian Aid, Asia Briefing No. $5^{8}$ (ICG, Brussels, 2006). See, for example, Yeni and Edward Blair, 'ICG Briefing Distorts and Misleads, Says OSI President', The Irrawaddy, 23 January 2007; and Aryeh Neier, 'Crisis Group Response to OSI Critique of Asia Briefing No. 58, Myanmar: New Threats to Humanitarian Aid', 17 January 2007.

${ }^{126}$ D. S. Mathieson, 'Competing for Reality in Burma', Global Knowledge, No. 2 (November 2006), pp. 57-61.

${ }^{127}$ For contrasting views on the sanctions debate see John Badgley (ed.), 'Reconciling Burma/Myanmar: Essays on US Relations with Burma', NBR Analysis, Vol. ${ }_{15}$, No. 1, March 2004 and The European Union and Burma: The Case for Targeted Sanctions (Burma Campaign UK, London, 2004). 
particularly successful in persuading the regime to abandon its core beliefs and adopt different policies on major issues.

On the basis of their views on this issue-correctly interpreted or not-some Burma scholars have been branded by Burmese and foreign activists alike with crude and misleading labels such as 'naive romantic', 'pro-regime apologist' or worse. This kind of language has even begun to creep into academic discourse. ${ }^{128}$ One expatriate opposition group has posted a long list of perceived 'enemies of the revolution' on the internet, apparently unaware of the similarities between such blacklists and the regime's own published catalogues of 'treasonous minions' and their 'traitorous cohorts abroad'. ${ }^{129}$ Both lists include the names of well-known academics and journalists. Some respected Burma scholars have been publicly abused for expressing their considered views on this subject, and at least one has received a death threat for taking a line deemed to be politically incorrect.

It would be expecting too much for exiled Burmese who have suffered at the hands of the military regime to be completely emotionally detached, but freedom of speech needs to be respected on both sides of the Burmese border.

The range of opinions expressed about Burma's problems has also exposed certain cultural differences, and possibly also a misunderstanding of accepted practices in the international academic world. These have added to the tensions felt within the Burma studies community. For example, most Burmese welcome the interest of foreign scholars in their country, but some do not. The regime has made its views about 'alien cultural influences' known ever since the days of Ne Win's rule. ${ }^{130}$ However, even expatriate commentators and journalists seeking the overthrow of the current military government have lashed out at 'hook nose farangs' who 'take to the podium and talk in academic absurdities on Burma'. ${ }^{131}$ Not all are racist, but some

${ }^{128}$ Monique Skidmore, 'Scholarship, Advocacy, and the Politics of Engagement in Burma (Myanmar): A Response to Helen James', The Australian Journal of Anthropology, Vol. 18 , No. 1 (2007), pp. 95-96.

${ }^{129}$ Yeni, 'A Blacklist Goes on Sale', The Irrawaddy, 14 June 2006 and The Conspiracy of Treasonous Minions Within the Myanmar Naing-Ngan and Traitorous Cohorts Abroad (Myanmar Ministry of Information, Yangon, 1989).

${ }^{130}$ See, for example, Prime Minister Khin Nyunt's address to the 11 th Myanmar Traditional Cultural Performing Arts Competitions, New Light of Myanmar, 4 November 2003, found at <http://www.myanmar.gov.mm/NLM-2003/enlm/ Novo4_h2.html>

131 Kanbawza Win, 'Some Clarification on the Need for US', Kao Wao Neres, No. 44, 14-29 May 2003, found at <http://www.ibiblio.org/obl/docs/KW44.htm>. See also 
expatriates still seem to feel that only 'native' Burmese (or even only ethnic Burmans) can really understand the complex situation in Burma, or have a right to express a view on the country's future.

In the same vein, foreign scholars writing about Burma have been condemned by some Burmese exiles for treating their country as 'some theoretical model ... learned in graduate school'. ${ }^{132}$ Westerntrained Burmese scholars striving for balance and accuracy in their writings have been accused by fellow expatriates of being members of a privileged elite that is perpetuating a form of intellectual imperialism. Similar pressures have been felt by some expatriate journalists. ${ }^{133}$ One Burmese magazine has stated that 'Commentators who can't share this sympathy with a suffering people don't deserve to be called "experts on Burma". ${ }^{134}$ Even one or two foreign scholars have argued that, for ethical reasons, it is incumbent on all those studying Burma to become 'engaged' with the fear and suffering of the Burmese people. ${ }^{135}$ While perhaps understandable in the current sensitive political climate, such an approach runs counter to the long established Western tradition of objective academic enquiry.

Inevitably, the authoritarian nature of the military government, the high levels of emotion flowing from the regime's harsh policies, different interpretations of developments in the country and the polarisation of views about the best approach to take towards the armed forces leadership, have all had an impact on modern Burma studies.

When Ne Win ruled Burma, some foreign academics consciously self-censored their public remarks, for fear of offending the regime. ${ }^{136}$ This was not necessarily out of sympathy for the socialist government, but mainly to ensure that they were still allowed access to the reclusive country for research, even for very limited periods. This phenomenon

Kanbawza Win, 'Crisis at the International Crisis Group', Mizzima News, December 2002.

132 'We Are Human Beings', The Irrawaddy, 6 November 2006.

${ }^{133}$ Lisa Brooten, 'Political Violence and Journalism in a Multiethnic State: A Case Study of Burma (Myanmar)', Journal of Communication Enquiry, Vol. 30, No. 4 (October 2006), pp. 354-73.

${ }^{134}$ Yeni, "Experts" Who Should Now East Their Words', The Irrawaddy, 20 September 2007 .

${ }^{135}$ Monique Skidmore, 'Scholarship, Advocacy, and the Politics of Engagement in Burma (Myanmar)', in Victoria Sanford and Asale Angel-Ajani (eds.), Engaged Observer: Anthropology, Advocacy, and Activism (Rutgers University Press, New Brunswick, 2006), pp. $42-59$

${ }^{136}$ Morse and Loerke, 'Introduction'. 
can also be seen under the new military government, which has already banned some of its more vocal critics, including scholars who have painted an unfavourable picture of military rule and foreigners believed to be sympathetic towards 'rebel' ethnic communities around Burma's borders. ${ }^{137}$ Expatriates who have family and friends still living in Burma-and are thus vulnerable to retribution from the regimeare in a particularly difficult position. Of concern to some scholars, however, is that they will be publicly denounced on the internet, by Burma-watchers outside the country, for having unfashionable views.

A few academics seem to welcome the notoriety that their more controversial views attract. Others have reacted strongly to such pressures, hitting out for example at the 'democracy jihad' that seeks to impose a new orthodoxy on Burma studies. ${ }^{138}$ Most have patiently attempted to explain their views, often in the face of continued and unwarranted criticism. ${ }^{139}$ Some academics, however, appear to have deliberately avoided publishing critical assessments on contentious topics, such as the Bush Administration's uncompromising approach to Burma, Aung San Suu Kyi's leadership style, the policies of the opposition political parties, or the practices of some ethnic insurgent groups. ${ }^{140}$ This seems to be out of a fear that, no matter how carefully worded and closely argued their comments may be, they will not be engaged in a civilised intellectual debate. Faced with such a prospect, they have chosen simply to focus on historical and thematic issues that are less controversial. ${ }^{141}$

Academics who choose to become active participants in the policy debate on Burma, or who openly support one political group against another, must expect responses from those who do not agree with their views. Similarly, there must always be room for different academic interpretations of Burma-related issues and developments. Indeed, this should be welcomed, and in many cases the debate, while lively,

137 One book of note in this regard is Christina Fink, Living Silence: Burma under Military Rule (Zed Books, London, 2001). See also Andrew Selth, 'Bertil Lintner and the State of Burma Studies', Asian Studies Review, Vol. 15, No. 2 (November 1991), pp. $265-71$.

138 Aung-Thwin, 'Parochial Universalism, Democracy Jihad and the Orientalist Image of Burma: The New Evangelism', pp. 483-505.

${ }^{139}$ See, for example, D. I. Steinberg, 'Minimising the Miasma in Myanmar', Foreign Policy in Focus, 18 January 2007, found at <http://www.fpif.org/fpiftext/3916>

${ }^{140}$ See, however, Kyaw Yin Hlaing, 'Aung San Suu Kyi of Myanmar: A Review of the Lady's Biographies', Contemporary Southeast Asia, Vol. 29, No. 2 (2007), pp. 359-76.

${ }^{141}$ Relevant here is D.S. Mathieson, 'The Bonfire of the Vanities', The Irrawaddy, June 2005 . 
has been conducted in a balanced and courteous fashion. Yet, all too often, scholars and journalists offering unpopular interpretations of Burmese history, reporting unpalatable facts or suggesting alternative policy approaches, have been subject to harsh and often personal criticism. The most virulent attacks seem to be made not on the basis of careful research or intellectual differences, but on political and 'moral' grounds. In such wars of words, the truth usually becomes the first victim. ${ }^{142}$

\section{Conclusion}

Since 1988, Burma has been accorded a higher priority in discussions of the Asia-Pacific region. As it has attracted greater international attention, so it has assumed a higher profile in the Academy.

After decades of neglect, the number of scholarly publications on Burma has grown dramatically, both in number and range. This high level of academic interest promised to continue for some years, even before the events of September 2007 once again thrust Burma into the world's headlines. Not only are scholars looking more closely at Burma and related issues but, over the past 19 years, the number of postgraduate students choosing to specialise in Burma has increased significantly. It is expected that they will make a notable contribution to future Burma studies, as researchers, authors and teachers. Also, the international Burma-watching community has been swollen by numerous private organisations and interested individuals, many of whom are gathering research material and contributing to the literature outside the formal confines of the Academy. The Burma studies scene is more active than ever.

Yet much remains to be done. There are aspects of Burmese society and culture that have been barely touched upon by scholars, and even in some well-trodden areas of study, like the country's history, politics and economics, there is wide scope for additional research and analysis. Burma is still poorly understood, compared to most other countries in the region. The brief survey above reveals numerous gaps in the literature that would benefit from attention. Not only could such works shed light on hitherto unexplored aspects of the country

142 'Burma Scholars and Moral Minefields', The Irrawaddy, 1 October 2002. Also relevant to this theme is Leon T. Hadar, 'Burma: US Foreign Policy as a Morality Play', Journal of International Affairs, Vol. 54, No. 2 (Spring 2001), pp. 411-26. 
but, by adding empirical data to the public record, they would have the added benefit of encouraging the inclusion of Burma in broader thematic and theoretical works. In such circumstances, comparative studies would be easier to conduct.

Yet, until the military government in Burma falls, or the current regime changes its attitude to academic research-neither of which are in prospect-field work in Burma will remain difficult. Changes will also need to occur outside the country. Burma studies demands greater recognition as a legitimate and worthwhile field of academic activity, and deserves more support from universities and funding institutions. Also, despite the current highly charged political climate, there must be a greater emphasis on the rigorous analysis and frank discussion of contemporary developments. It is to be hoped that Burma-watchers of all kinds, both within the Academy and outside it, can pursue their shared interests in a collegiate and civilised manner, and in an atmosphere that tolerates-indeed encouragesintellectual differences. For failure to do this will inevitably be at the cost of original research and fresh insights into Burma, a country that has for too long remained hidden behind walls of ignorance and misunderstanding. 